Biol. Stud. 2009: 3(1); 57-64 • DOI: https://doi.org/10.30970/sbi.0301.022

www.http://publications.Inu.edu.ua/journals/index.php/biology

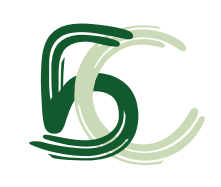

UDC 577.155 .2

\title{
DNA-HYDROLYZING ACTIVITY OF SIgA-ABZYMES OF HUMAN MILK IS DIFFERENTIALLY INHIBITED BY NUCLEOSIDE TRIPHOSPHATES
}

\author{
Yu. Ya. Kit \\ Institute of Cell Biology, NAS of Ukraine \\ 14-16, Drahomanov St., Lviv 79005, Ukraine \\ e-mail:kit@cellbiol.Iviv.ua
}

It is known that human milk contains secretory immunoglobulines $\mathrm{A}$ (slgA-abzymes) possessing affinity to mammalian DNA and capacity to cleave plasmid DNA. Regulation of DNA-hydrolyzing activity of those slgA-abzymes is poorly studied. Here we investigate the effect of nucleoside triphosphates towards the DNase activity of slgA-abzymes which were purified from human milk by a sequential chromatography on protein A-agarose, DEAE-Fractogel, and DNA-cellulose. By using DNA-hydrolysing assay, we revealed that $1 \mathrm{mM}$ ATP and $1 \mathrm{mM}$ dATP markedly reduced the cleavage of linear form of plasmid DNA by slgA-abzymes, while the effect of GTP, CTP, TTP and dGTP was much weaker. dCTP and dTTP did not influence DNase activity of the slgA-abzymes. Possible mechanisms of nucleotide-mediated inhibition of the DNase activity of slgA-abzymes are discussed.

Key words: abzymes, secretory immunoglobulin A, human milk, DNA-hydrolyzing activity.

\section{INTRODUCTION}

DNA-hydrolyzing IgGs were originally discovered in blood serum of patients with the autoimmune disease - systemic lupus erythromatosis [1]. Antibodies possessing similar activity have been revealed in blood serum of patients with various types of autoimmune and with non-autoimmune diseases [2, 3]. Besides, natural catalytic antibodies which belong to slgA and IgG classes have been found in woman's colostrum and milk [2, 4]. Those abzymes possessed a capacity to phosphorylate proteins [5, 6], lipids [7, 8], and polysaccharides [9]. They also cleaved plasmid DNA [10], tRNA [11], nucleotides [12], polysaccharides [13], and casein [14]. Regulation of the catalytic activity of abzymes of human milk by endogenous effectors remains poorly studied. The presence of IgGs in healthy human's blood serum which inhibited protein kinase activity of slgAabzymes was demonstrated [6]. Besides, it was found that oligodeoxynucleotides stimulated protein kinase activity of slgA-abzymes $[15,16]$. Here we show that ribo- and deoxyribonucleoside triphosphates inhibit DNA-hydrolyzing activity of slgA-abzymes isolated from human milk, and that effect significantly depends on the nucleotide type. 


\section{MATERIALS AND METHODS}

\subsection{Isolation of slgA Abzs from human milk}

Fraction enriched with slgA was obtained, as described elsewhere [10]. Milk (10 ml) was taken from healthy human mothers and centrifuged for $30 \mathrm{~min}$ at $6000 \mathrm{~g}$. The lipid phase was removed and proteins were precipitated with the ammonium sulphate at $50 \%$ saturation. The pellet was dissolved in TBS (20 mM Tris- $\mathrm{HCl}, \mathrm{pH} 7.5,150 \mathrm{mM} \mathrm{NaCl})$, and loaded on $3 \mathrm{ml}$ protein A-Agarose Fast Flow (Sigma) column. The column was washed with TBS containing $0.5 \%$ Triton X-100, and antibodies were eluted with $100 \mathrm{mM} \mathrm{Gly}-\mathrm{HCl}$,

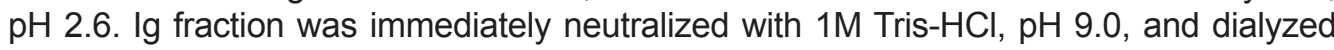
against of buffer $\mathrm{A}$ (10 mM Tris-HCl, $\mathrm{pH} 7.0$ ). Then slgA was separated from lgG by chromatography on Fractogel TSK DEAE-650 (M). slgA was eluted with $10 \mathrm{mM}$ Tris- $\mathrm{HCl}$, $\mathrm{pH} 7.0,100 \mathrm{mM} \mathrm{NaCl}$ and loaded on a column containing $3 \mathrm{ml}$ glutaraldehyde-modified calf thymus DNA immobilized on cellulose $\left(1000 \mathrm{~A}_{260}\right.$ units to $1 \mathrm{~g}$ cellulose). Proteins were eluted with $50 \mathrm{mM} \mathrm{NaOH}$ and dialyzed for $24 \mathrm{~h}$ against $20 \mathrm{mM}$ Tris- $\mathrm{HCl}, \mathrm{pH}$ 7.0. slgAs, possessing affinity to DNA-cellulose (anti-DNA slgA) were concentrated on mini-column containing $50 \mu$ l Toyopearl TSK DEAE-650 (M). Anti-DNA slgAs were eluted with $100 \mathrm{mM}$ $\mathrm{NaCl}$ in buffer A, and analyzed by SDS-electrophoresis in 12\% PAGE [17], and further used in DNA-hydrolyzing activity assay.

\subsection{Size-exclusion chromatography (SEC)}

Size-exclusion chromatography of the purified anti-DNA slgA from human milk was performed in 0.1 M Gly-HCl, pH 2.6, on Toyopearl TSK HW-55 (Toyo Soda, Japan) column $(180 \times 5 \mathrm{~mm})$ equilibrated with the same solution. The column was previously calibrated with protein molecular weight standards (Serva, Germany). Anti-DNA slgAs were precipitated with $50 \%$ ammonium sulphate, the pellet was dissolved in $30 \mu \mathrm{l}$ of $0.1 \mathrm{M} \mathrm{Gly}-\mathrm{HCl}$, pH 2.6, and subjected to SEC. Individual fractions (each $300 \mu \mathrm{l}$ ) were collected, dialyzed overnight against $20 \mathrm{mM}$ Tris- $\mathrm{HCl}, \mathrm{pH} 7.5,100 \mathrm{mM} \mathrm{NaCl}, 5 \mathrm{mM} \mathrm{MgCl}_{2}$, analyzed by SDSelectrophoresis in 7-18.5\% gradient PAGE, and examined for DNA-hydrolyzing activity.

\subsection{DNA-hydrolyzing activity assay}

Linear form of plasmid DNA was obtained via cleavage of super-coiled and relaxed forms of DNA plasmid pBR322 by EcoR1 (Fermentas, Lithuanian Republic) during $18 \mathrm{~h}$ at $37^{\circ} \mathrm{C}$. DNA-hydrolysing activity of the anti-DNA slgA preparation was determined using assay mixture containing $20 \mathrm{mM}$ Tris- $\mathrm{HCl}, \mathrm{pH} 7.5,100 \mathrm{mM} \mathrm{NaCl}, 5 \mathrm{mM} \mathrm{MgCl}, 3 \mu \mathrm{g}$ of the linear pBR322 plasmid DNA and $0.5 \mathrm{mg} / \mathrm{ml}$ of anti-DNA slgAs. The reaction mixture (total volume $50 \mu \mathrm{l}$ ) was incubated for $1 \mathrm{hr}$ at $37^{\circ} \mathrm{C}$ and analysed by electrophoresis in $1 \%$ agarose (89 mM Tris-borate running buffer, $\mathrm{pH} 8.3,2 \mathrm{mM}$ EDTA). The gel was stained with ethydium bromide. For examination of DNA-hydrolysing activity of protein fractions obtained by SEC, $1 \mu \mathrm{g}$ of linear pBR322 plasmid DNA was added to $25 \mu$ l aliquots. The reaction mixture was incubated $2 \mathrm{~h}$ at $37^{\circ} \mathrm{C}$ and separated by electrophoresis in $1 \%$ agarose at the same conditions. To study the effect of nucleotides towards DNA-hydrolyzing activity of slgA-abzymes, different amounts of ribo- or deoxyribonucleoside triphosphates (Sigma) and $0.5 \mathrm{mg} / \mathrm{ml}$ of anti-DNA slgA were added to the reaction mixture. The reaction mixture was incubated for $1 \mathrm{~h}$ at $37^{\circ} \mathrm{C}$, and the products of hydrolysis were examined, as described above. Relative quantity of linear plasmid DNA on the gel was calculated using Gel-Pro Analyzer 4.0 program. 


\section{RESULTS}

\subsection{DNase activity of slgA-abzymes}

When studying abzyme-mediated catalysis, it is important to use highly purified preparations of antibodies in order to exclude presence of any possible enzymatic contamination. For purification of DNA-hydrolysing antibodies, the scheme has been developed that is based on two main characteristics - antibody nature and DNA specificity [18]. By using this approach, DNA-hydrolyzing abzymes have been isolated and characterized from blood serum of patients with different diseases, and from colostrum and milk of healthy women $[5,10]$. We used similar protocol for purification of DNA-hydrolyzing slgA from human milk. Earlier, it was found that immobilized protein $A$ is an optimal sorbent at the first step of slgA-abzymes purification procedure, since for an unknown reason, it possesses higher affinity for slgA-abzymes then for slgA lacking the catalytic activity [2, 4-12]. Therefore, a fraction of milk antibodies was first purified by chromatography on Protein A-Agarose under conditions that remove non-specifically bound proteins (Fig 1a, lane 1). Next, IgG and slgA were separated by the ion-exchange chromatography on DEAEFractogel column. In order to isolate anti-DNA slgAs, highly purified slgA preparation (Fig.1a, lane 2) was subjected to affinity chromatography on DNA-cellulose column. Earlier, we established that slgA-abzymes remain stable at alkaline conditions $[6,11]$. That allowed us to use $50 \mathrm{mM} \mathrm{NaOH}$ for a final elution of anti-DNA sigA from the DNA-cellulose column. Fractions isolated in that way consisted of anti-DNA slgA (Fig 1a, lane 3). They were further used in DNA-hydrolyzing assays. Since abzymes with DNase activity possessed a capacity to induce multiple cleavage of a linear plasmid DNA into short and medium size oligodeoxyrybonucleotides [2], it was used as a substrate in DNA-hydrolyzing assay. Incubation of anti-DNA slgAs isolated from human milk with a linear plasmid DNA showed their DNase activity (Fig. 1b, lane 2). The lack of contaminating nucleases attached to slgA, was additionally checked by size-exclusion chromatography under the acidic conditions (Fig. 2a). As shown in Fig 2b, anti-DNA slgA showed one chromatographic peak containing polypeptides whose molecular weights corresponded to a secretory component, $\mathrm{H}$-, L-, and J-chains of slgA [19]. Examination of DNA-hydrolyzing activity of chromatographic fractions displayed a coincidence of the capacity to cleave plasmid DNA exclusively with a peak containing slgA (Fig. $2 c$ ). The rest of the eluted fractions were

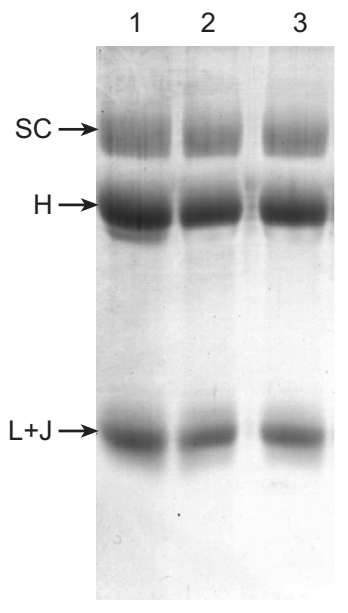

a

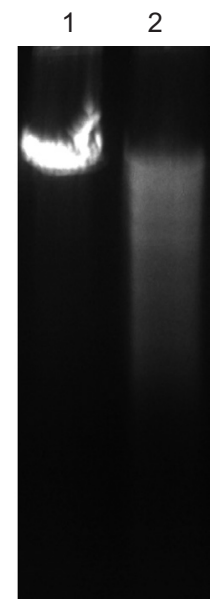

$b$
Fig.1. Purification of slgA-Abzs from human milk with following examination of their DNA-hydrolyzing activity. a - SDS-electrophoresis in 12\% PAGE slgA preparations obtained by chromatography on Protein A-agarose (lane 1); DEAE-Fractogel (lane 2), and DNAcellulose (lane 3). Coomassie G-250 stained the gel. $b$ - electrophoretic analysis of plasmid DNA in $1 \%$ agarose after its incubation with slgA preparation, purified by chromatography on DNA-cellulose (anti-DNA slgA). Lane 1 - linear pBR322 DNA incubated alone; lane 2 - DNA incubated with anti-DNA slgA. Ethydium bromide stained the gel. Arrows show a position of slgA polypeptides slgA: SC - secretory component, $\mathrm{H}$ - heavy chain, $\mathrm{L}+\mathrm{J}-$ light and joint chains. Since $\mathrm{L}$ - and J-chains of slgA do not separate in this electrophoretic condition [19], they are marked onto the gel, as one polypeptide band 

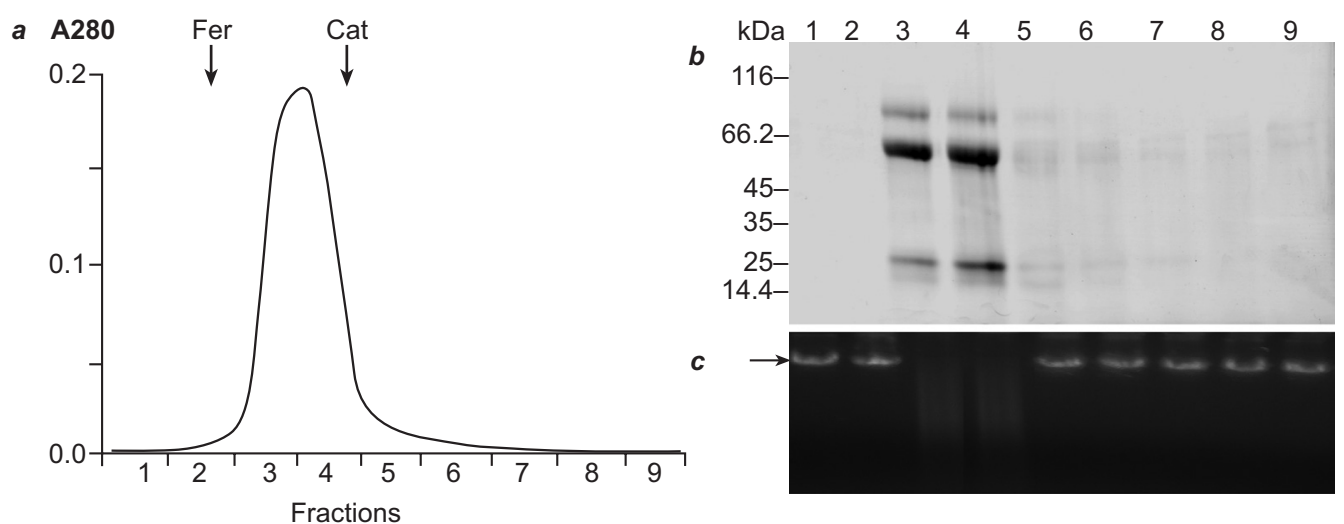

Fig. 2. Verification of impurities absence by size-exclusion chromatography. Purified anti-DNA slgAs from human milk were subjected to size-exclusion chromatography on Toyopearl TSK HW-55 F column in $0.1 \mathrm{M}$ Gly- $\mathrm{HCl}, \mathrm{pH} 2.6$ (a). Fractions were collected, renaturated and analyzed by SDS-electrophoresis in 7-18.5\% gradient PAGE $(b)$. Aliquots of fractions were incubated with plasmid DNA, followed by electrophoresis in 1\% agarose in TBE, pH 8.3 (c). Ferritin, 450 kDa; Catalase from bovine leaver, $240 \mathrm{kDa}$. Arrow shows plasmid DNA position on the gel

catalytically inactive, thus indicating that DNA-hydrolyzing activity co-eluted with slgA. The slgA fraction isolated from total slgA pool of anti-DNA slgA by size-exclution chromatography in acidic condition displayed approximately 35\% of the initial DNA-hydrolyzing activity after renaturation. Lack of the catalytic activity observed after the chromatographic run is a consequence of e prolonged exposure of slgA to denaturing condition.

These data demonstrated that the DNA-hydrolyzing activity of the anti-DNA sigA preparations under study was associated with the antibodies, and that ruled out an involvement of any DNase contaminants.

\subsection{Inhibitory effect of nucleoside triphosposphates towards DNase activity of slgA-abzymes}

Earlier, we have demonstrated that slgAs isolated from human milk can interact with ATP $[5,6]$. Affinity modification of slgA by $\left[{ }^{32} \mathrm{P}\right]$-labelled reactive derivative of ATP revealed that the ATP-binding sites are located on both $\mathrm{L}$ - and $\mathrm{H}$-chains of slgA molecule [20]. Here we addressed a question if ATP could be involved in regulation of DNAhydrolyzing activity of slgA-abzymes. To check that suggestion, ATP was added in different concentrations to the reaction mixture. Figure 3 illustrates that ATP in a concentration-depended manner inhibits the cleavage of plasmid DNA by slgA-abzymes isolated from milk of healthy human. The DNA-hydrolysing activity of slgA-abzymes was markedly reduced, when the ATP concentration was increased from 0.1 to $0.5 \mathrm{mM}$ (Fig. 2 , lane 3,4$)$. The increasing of ATP amount to 1-3 mM almost completely blocked DNA cleavage by the slgA-abzymes (Fig. 3 , lane 5,6 ).

We also checked whether others nucleoside triphosphates could affect DNA-hydrolysing activity of slgA-abzymes. Since $1 \mathrm{mM}$ ATP effectively blocked DNase activity of slgA-abzymes, we used the same concentration of a panel of nucleoside triphosphates in the DNA-hydrolyzing assay. As shown in Figure $4 a$, ribonucleoside triphosphates decreased DNase activity of slgA-abzymes in the order: ATP $>$ GTP $>C T P>T T P$. The inhibiting effect of deoxyribonucleotides was different from the effect of ribonucleotides. Opposite to CTP and TTP which were moderate inhibitors of that DNase activity (Fig. 4a, lanes $4,5)$, dCTP and dTTP in $1 \mathrm{mM}$ concentration failed to reduce plasmid DNA cleavage by 


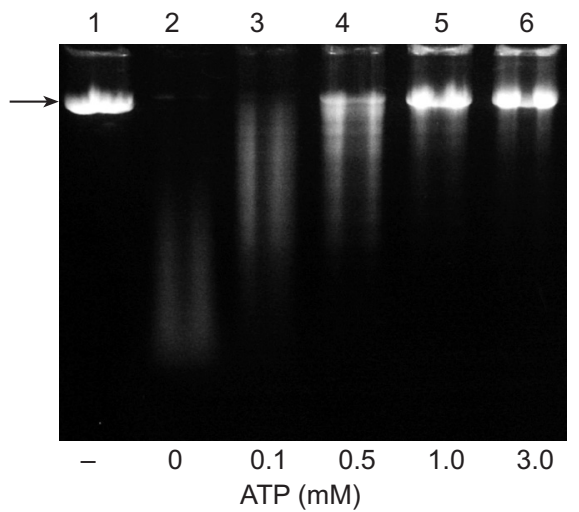

14Fig. 3. Influence of different concentration ATP on DNAhydrolyzing activity of slgA-Abzs isolated from human milk. Lane1 - linear pBR322 DNA incubated alone; lane 2 - DNA incubated with slgA-abzymes; lanes 3-6, DNA incubated with slgA-abzymes in the presence 0.1-3.0 mM ATP. Arrow shows plasmid DNA position on the gel
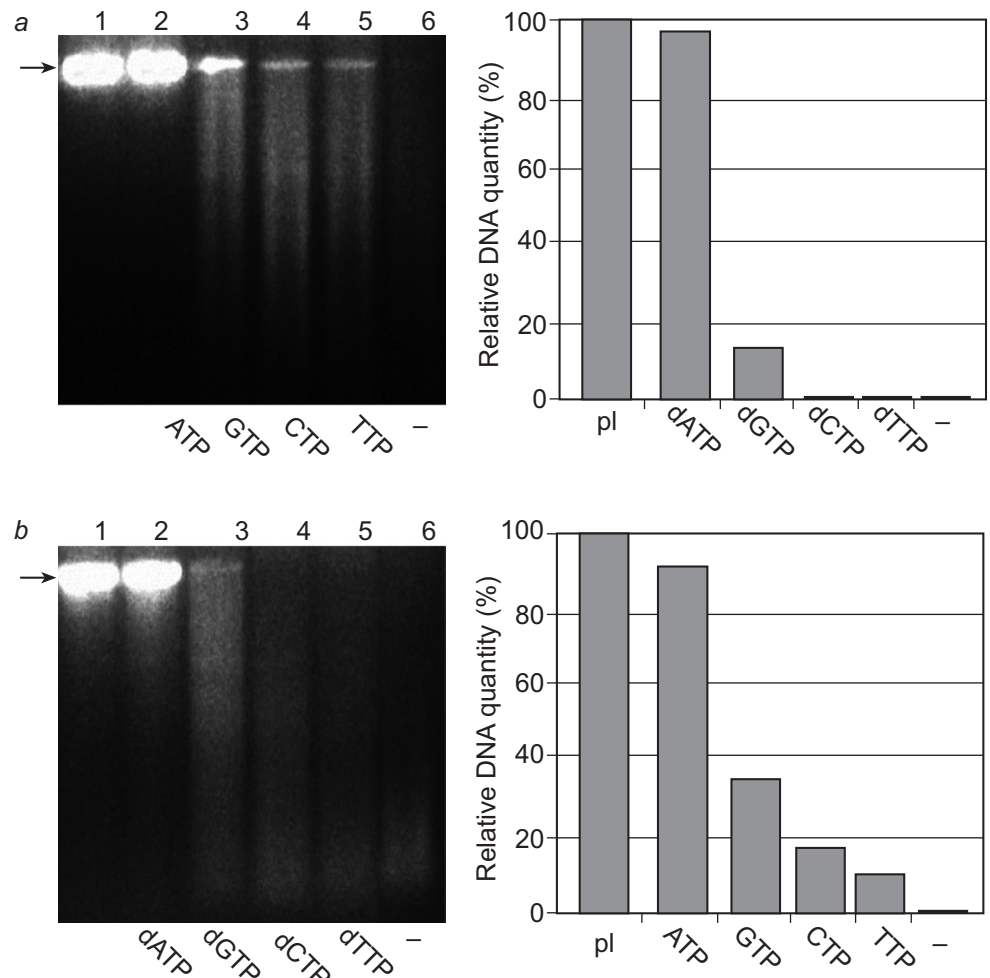

Fig. 4. Influence of nucleotide triphosphates on DNA-hydrolyzing activity of slgA-abzymes isolated from human milk. Cleavage of plasmid DNA by slgA-abzymes in the presence of ribonucleoside triphosphates (a), or deoxyribonucleoside triphosphates (b). Lanes 1 - linear pBR322 DNA incubated alone; lanes 2-5 - plasmid DNA incubated with slgA-abzymes in the presence of $1.0 \mathrm{mM}$ nucleotides; lane 6 - DNA incubated in absence of nucleotides. Arrows identify plasmid DNA position on the gels. Relative quantity of the linear pBR322 DNA on the gels is shown

slgA-abzymes (Fig 4b, lanes 4, 5). Only a weak inhibitory effect was detected in case of dGTP (Fig 4b, lane 3), however, it was essentially lower than the effect of GTP (Fig 4a, lane 3). An interesting result was obtained when dATP was used as effector. In that case, there was no big difference between the inhibitory effect of dATP and ATP, which both effectively blocked DNase activity of slgA-abzemes (Fig 4a, lane 2). 


\section{DISCUSSION}

Here we demonstrated that specific nucleoside triphosphates reduced DNA-hydrolyzing activity of slgA-abzymes isolated from milk of healthy human. There are two possible explanations of the mechanisms of such effect. The $1^{\text {st }}$ one is based on data showing that the catalytic center of slgA-abzymes possessing DNase activity is located in the light chain, while the DNA-binding center is predominantly formed by its heavy chain [10]. Thus, it is possible that high concentrations of ATP and dATP block binding the plasmid DNA to the DNA-binding center of slgA-abzymes, and that leads to inhibition of their catalytic activity.

The $2^{\text {nd }}$ potential mechanism is based on the data showing that a pool of anti-DNA slgAs isolated from human milk by DNA-cellulose chromatography contains slgA-abzymes possessing protein kinase activity $[15,16]$. Since both slgA-abzymes possessing protein kinase and nuclease activities were purified in similar way, it was reasonable to assume that the slgA-protein kinases might phosphorylate the slgA-nucleases or both those activities are intrinsic properties of the same slgA-abzymes. Thereby, it is possible that the nucleotidedependent inhibitory effect could be realized through phosphorylating the polypeptide sites involved in binding plasmid DNA or providing its catalytic degradation. That suggestion could also confirm the data showing that slgA-abzymes possessing protein kinase activity isolated from human milk, can use, as substrate, not only ATP, but other ribo- and deoxirybonucleoside triphosphates, as well [6]. The involvement of phosphorylation in the regulation of DNase activity of slgA-abzymes looks very attractive thought it is difficult to explain why an effective inhibitory concentration of nucleotides is apparently higher than that which is necessary to provide the phosphorylation reaction [16].

Since human milk contains different nucleotides [21], it was reasonable to suggest that some endogenous nucleotides could be involved in regulation of DNA-hydrolyzing activity of slgA-abzymes. Though a biological role of slgA-abzymes stays unknown, it was suggested that they participate in providing a defence of newborn's mucous layers against the pathogenic microflora $[10,11]$.

We hypothesise that a protective role of slgA-abzymes could be realized in another way. slgA-abzymes belong to antibodies which transfer in mucosal fluids by means of receptormediated transcytosis through mucosal epithelial cells [22]. It was demonstrated that their passing through the lining epithelial cells of mucous membranes during secretion, IgA antibodies might participate in neutralizing intracellular pathogens, such as viruses [23]. Taking into account these data, it was reasonable to suggest, that slgA-abzymes are involved in the intracellular neutralization of viruses via degradations of their DNA or RNA. Besides, complement-independent cytotoxicity of IgG-abzymes with DNase activity, isolated from blood sera of patients with lymphoproliferative or autoimmune diseases, have been described [24, 25]. Thereby, the cytotoxic activity of slgA-abzymes towards the epithelial cells might also exist. It has been established, that slgA-abzymes with DNase activity also possessed RNase activity $[2,10]$. Thus, one cannot exclude, that the slgA-abzymes which penetrated in the cell, can hydrolyze intracellular RNA or nuclear DNA, and, in that way, affect metabolism of the epithelial cells. Since ATP and dATP possess an ability to block DNA-hydrolyzing activity of slgAabzymes, it might be suggested that such metabolic disturbance is protected by high concentration of nucleoside triphosphates that are present in those cells.

\section{Acknowledgment}

The work was supported by the Integrating Grant of National Academy of Sciences of Ukraine and Siberian Division of Russian Academy of Sciences. 


\section{ГІДРОЛІЗ ДНК sIgА-АБЗИМАМИ МОЛОКА ЛЮДИНИ ДИФЕРЕНЦІЙНО ІНГІБУЄТЬСЯ НУКЛЕОТИДТРИФОСФАТАМИ}

Ю. Я. Kim

Інститут біології клітини НАН України вул. Драгоманова, 14-16, Львів 79005, Україна

Відомо, що молоко людини містить секреторні імуноглобуліни A (slgA-абзими), які володіють спорідненістю до ДНК ссавців і здатні гідролізувати плазмідну ДНК. Регуляція ДНК-азної активності цих абзимів залишається маловивченою. Метою роботи було дослідити вплив нуклеотидтрифоссратів на ДНК-азну активність slgAабзимів, очищених із молока людини послідовними хроматографріями на колонках із протеїн А-агарозою, ДЕАЕ-фрактогелем і ДНК-целюлозою. У результаті проведеного аналізу встановлено, що АTP (1 мM) і dATP (1 мМ) практично повністю інгібують розщеплення лінійної форми ДНК плазміди slgA-абзимами. При цьому інгібувальний ефект GTP, CTP, TTP і dGTP на ДНК-азну активність slgA-абзимів був значно нижчий, ніж у ATP і dATP, a dCTP і dTTP помітно не впливали на швидкість гідролізу плазмідної ДНК цими абзимами. У роботі обговорено можливі механізми інгібувальної дії нуклеотидтрифоссфатів на ДНК-азну активність slgA-абзимів молока людини.

Ключові слова: абзими, секреторний імуноглобулін А, молоко людини, ДНКазна активність.

\section{ГИДРОЛИЗ ДНК sIgА-АБЗИМАМИ МОЛОКА ЧЕЛОВЕКА ДИФФЕРЕНЦИАЛЬНО ИНГИБИРУЕТСЯ НУКЛЕОТИДТРИФОСФАТАМИ}

Ю. Я. Kum

Институт биологии клетки НАН Украины ул. Драгоманова, 14-16, Львов 79005, Украина

Известно, что молоко человека содержит секреторные иммуноглобулины A (slgAабзимы), которые обладают сродством к ДНК млекопитающих и способны гидролизовать плазмидную ДНК. Регуляция ДНК-азной активности этих абзимов остается малоизученной. Целью работи было исследовать влияние нуклеотидтрифосфатов на ДНКазную активность slgA-абзимов, очищенных из молока человека последовательными хроматографиями на колонках с протеин А-агарозой, ДЕАЕ-фрактогелем и ДНКцеллюлозой. В результате проведенного анализа установлено, что ATP (1 мM) и dATP (1 мМ) практически полностью ингибируют расщепление линейной формы ДНК плазмиды slgA-абзимами. При этом ингибирующий ефффект GTP, CTP, TTP и dGTP на ДНК-азную активность slgA-абзимов был значительно ниже, чем у ATP и dATP, a dCTP и dTTP заметно не влияли на скорость гидролиза плазмидной ДНК этими абзимами. В роботе обсуждаются возможные механизмы ингибирующего действия нуклеотидтрифосфратов на ДНК-азную активность slgA-абзимов молока человека.

Ключевые слова: абзимы, секреторный иммуноглобулин А, молоко человека, ДНК-азная активность. 
1. Shuster A.M., Gololobov G.V., Kvashuk O.A. et al. DNA hydrolyzing autoantibodies. Science, 1992; 256 (5057): 665-667.

2. Nevinky G.A., Buneva V.N. Human cathalytic RNA- and DNA-hydrolyzing antibodies. J. Immunol. Methods, 2002; 269 (1-2): 235-249.

3. Gabibov A.G., Ponomarenko N.A., Tretyak E.B. et al. Catalytic autoantibodies in clinical autoimmunity and modern medicine. Autoimmun. Rev, 2006; 5 (5): 324-330.

4. Nevinsky G.A., Buneva V.N. Catalytic antibody in healthy humans and patients with autoimmune and viral diseases. J. Cell. Mol. Med., 2003; 7 (3): 265-276.

5. Kit Y.Y., Semenov D.V., Nevinsky G.A. Phosphorylation of human milk proteins by human catalytic secretory immunoglobulin A. Biochem. Mol. Biol. Int, 1996; 36 (3): 521-527.

6. Nevinsky G.A., Kit Y.Y., Semenov D.V. et al. Secretory immunoglobulin A from human milk catalyzes milk protein phosphorylation. Appl. Biochem. Biotechnol, 1998; 75 (1): 77-91.

7. Kit Y.Y., Shipitsin M.V., Semenov D.V. et al. Phosphorylation of lipids tightly bound to secretory immunoglobulin $\mathrm{A}$ in antibody fractions from human breast milk possessing protein kinase activity. Biochemistry (Moscow), 1998; 63 (6): 719-724.

8. Gorbunov D.V., Karataeva N.A., Buneva N.V., Nevinsky G.A. Lipid kinase activity of antibodies from human milk of clinically healthy human mothers. Biochim. Biophys. Acta, 2005; 1735 (3): 153-166.

9. Karataeva N.A., Gorbunov D., Prokudin I.V. et al. Human milk antibodies with polysaccharide kinase activity. Immunol. Lett, 2006; 103 (1): 58-67.

10. Nevinsky G.A., Kanyshkova T.G., Semenov D.V. et al. Secretory immunoglobulin A from healthy human mothers' milk catalyzes nucleic acid hydrolysis. Appl. Biochem. Biotechnol, 2000; 83 (1-3): 115-129.

11. Buneva V.N., Kanyshkova T.G., Vlassov A.V. et al. Catalytic DNA- and RNA-hydrolyzing antibodies from milk of healthy human mothers. Appl. Biochem. Biotechnol, 1998; 75 (1): 63-76.

12. Semenov D.V., Kanyshkova T.G., Karotaeva N.A. et al. Catalytic nucleotide-hydrolyzing antibodies in milk and serum of clinically healthy human mothers. Med. Sci. Monit, 2004; 10 (2): 23-33.

13. Savel'ev A.N., Kanyshkova T.G., Kulminskaya A.A. et al. Amylolytic activity of IgG and slgA immunoglobulins from human milk. Clin. Chim. Acta, 2001; 314 (1-2): 141-52.

14. Odintsova E.S., Buneva V.N., Nevinsky G.A. Casein-hydrolyzing activity of slgA antibodies from human milk. J. Mol. Recognit, 2005; 18 (5): 413-421.

15. Kit Y.Y., Semenov D.V., Kuligina E.V., Richter V.A. Influence of nucleic acids and polysaccharides on phosphotransferase activity of preparations of secretory immunoglobulin $A$ from human milk. Biochemistry (Moscow), 2000; 65 (2): 237-243.

16. Kit Y, Kuligina E., Semenov D, Richter V. Oligodeoxyadenylate stimulates the protein kinase activity of anti-DNA slgA from human milk. Acta. Biochim. Pol, 2002; 5 (1): 291-294.

17. Laemmli U.K. Cleavage of structural protein during the assembly of the head of bacteriophage T4. Nature, 1970; 227 (5259): 680-684.

18. Gololobov G.V., Chernova E.A., Shchourov D.V. et al. Cleavage of supercoiled plasmid DNA by autoantibody Fab fragment: application of the flow linear dichroism technique. Proc. Natl. Acad. Sci. USA, 1995; 92 (1): 254-275.

19. Garsia-Pardo A., Lamm M.E., Plaut A.G., Frangione B. J-chain is covalently bound to both subunits in human secretory A. J. Biol. Chem, 1981; 22 (22): 11734-11738.

20. Kit Yu. Ya., Yakubov L.A., Kuligina E.V., Rikhter V.A. Interaction of oligonucleotides and ATP with slgA possessing protein kinase activity. Ukr. Biokchim. Zh, 2003; 75 (2): 63-67.

21. Schlimme E., Martin D., Meisel H. Nucleosides and nucleotides: natural bioactive substances in milk and colostrums. Br. J. Nutr, 2000; 84 (1): 59-68.

22. Lamm M.E. Current concepts in mucosal immunity. IV. How epithelial transport of IgA antibodies relates to host defence. Am. J. Physiol, 1998; 274 (4 Pt 1): 614-617.

23. Lamm M.E., Nedrud J.G., Kaetzel C.S., Mazanec M.B. IgA and mucosal defense. APMIS. 1995; 103 (4): 241-246.

24. Kozyr A.V., Kolesnikov A.V., Aleksandrova E.S et al. Novel functional activities of anti-DNA autoantibodies from sera of patients with lymphoproliferative and autoimmune diseases. Appl. Biochem. Biotechnol, 1998; 75 (1): 45-61

25. Kozyr A.V., Sashchenko L.P., Kolesnikov A.V. et al. Anti-DNA autoantibodies reveal toxicity to tumor cell lines. Immunol. Lett, 2002; 80 (1): 41-47.

Одержано: 11.02.2009

ISSN 1996-4536 • Біологічні Студії / Studia Biologica • 2009 • Том 3/№1 • С. 57-64 